\title{
Evaluation of Mosquito (Diptera: Culicidae) Species Richness using Two Sampling Methods in the Hydroelectric Reservoir of Simplício, Minas Gerais, Brazil
}

Author(s): Jeronimo Alencar, Viviane Soares de Mello, Nicolau Maués Serra-Freire, Júlia dos Santos Silva, Fernanda Morone and Anthony Érico Guimarães

Source: Zoological Science, 29(4):218-222.

Published By: Zoological Society of Japan

DOI: http://dx.doi.org/10.2108/zsj.29.218

URL: http://www.bioone.org/doi/full/10.2108/zsj.29.218

BioOne (www.bioone.org) is a nonprofit, online aggregation of core research in the biological, ecological, and environmental sciences. BioOne provides a sustainable online platform for over 170 journals and books published by nonprofit societies, associations, museums, institutions, and presses.

Your use of this PDF, the BioOne Web site, and all posted and associated content indicates your acceptance of BioOne's Terms of Use, available at www.bioone.org/page/terms_of_use.

Usage of BioOne content is strictly limited to personal, educational, and non-commercial use. Commercial inquiries or rights and permissions requests should be directed to the individual publisher as copyright holder. 


\title{
Evaluation of Mosquito (Diptera: Culicidae) Species Richness Using Two Sampling Methods in the Hydroelectric Reservoir of Simplício, Minas Gerais, Brazil
}

\author{
Jeronimo Alencar ${ }^{1 *}$, Viviane Soares de Mello ${ }^{1}$, Nicolau Maués Serra-Freire $^{2}$, \\ Júlia dos Santos Silva ${ }^{1}$, Fernanda Morone ${ }^{1}$, and Anthony Érico Guimarães ${ }^{1}$ \\ ${ }^{1}$ Diptera Laboratory, Oswaldo Cruz Institute (Fiocruz), Av. Brasil 4365, \\ CEP: 21040-360 Manguinhos, Rio de Janeiro, Brazil \\ ${ }^{2}$ Ixodides Laboratory, Oswaldo Cruz Institute (Fiocruz), Av. Brasil 4365, \\ CEP: 21040-900 Manguinhos, Rio de Janeiro, Brazil
}

\begin{abstract}
We compared two types of light traps used for monitoring mosquito abundance in the hydroelectric reservoir of Simplício, Além Paraíba - Minas Gerais. Mosquitoes were captured bimonthly using automatic CDC and Shannon traps before the filling of the hydroelectric plant reservoir from December 2008 to December 2009. In total, 1474 specimens from 13 genera were captured. Among the captured specimens, several species known to be vectors of disease-causing agents for humans and/or animals were identified, including Anopheles aquasalis, Aedes albopictus, Coquillettidia venezuelensis, Haemagogus leucocelaenus, and Aedes scapularis. Sampling efficacy between the four capture sites was not found to be significantly different, irrespective of species captured or type of trap used. Poor correlation $\left(r_{x, y}=-0.0444\right)$ between the number of mosquito species and capture site was observed when not influenced by the type of trap used. Among the installation sites of the CDC and Shannon traps in the areas investigated, CDC traps fixed in livestock shelters obtained an overall higher abundance of species captured.
\end{abstract}

Key words: Culicidae, species richness, CDC traps, Shannon traps, hydroelectric

\section{INTRODUCTION}

Culicidae are distributed across the six biogeographic regions of the world. The Neotropical region contains the highest abundance of Culicidae, with $31 \%$ of known species found in this region, followed by the Oriental (30\%), Australian and African (22\%), and Nearctic (5\%) regions. The Palaearctic region presents the lowest level of abundance, with only $3 \%$ of known species (Rueda, 2008). Studies on faunal diversity facilitate the identification, monitoring, and controlling of Culicidae populations. These activities are especially important given the impact of modern-day environmental changes caused by human activity, including both the degradation and/or preservation of a given area, and their epidemiological implications (Forattini and Massad, 1998).

Forattini (1991) showed that the effects of urbanization can be observed by the continuously increasing number of urban centers, which can result in intense and profound perturbation of the environment, and the relationship of human beings with nature.

Given its vast, potentially hydrographic territory, Brazil prioritizes the use of hydropower as the basis of its energy supply, which is needed to meet the demand caused by industrial growth and urban sprawl. For Brazil, hydropower

\footnotetext{
* Corresponding author. Tel. : : +55-21-2562-1238;

Fax : +55-21-2562-1308;

E-mail: jalencar@ioc.fiocruz.br
}

is considered the best technical and economical solution to environmental risks and costs, as compared to nuclear power.

Such hydroelectric projects nonetheless have major, primarily negative, environmental impacts, which can be observed during and beyond the lifetime of a given plant, as well as throughout the affected area.

The construction of the Balbina (Amazonas), Samuel (Rondônia), and particularly Tucuruí (Pará) hydroelectric plants can be included in the recent history of environmental impacts of such projects, as reported by Guimarães et al. (1997). In all these cases, the formation of large reservoirs was accompanied by the introduction of displaced human populations coming from regions known to be endemic to mosquito-borne diseases, including malaria.

Since environmental changes can become dangerous when direct contact between Culicidae and the local human population exists, the study of mosquito fauna is of immeasurable importance in areas in which the environment has been altered.

The objective of this study was to evaluate the composition of mosquito fauna and to compare the use of two types of light traps (CDC and Shannon) as methods of mosquito sampling in implementation areas of the hydroelectric reservoir of Simplício (Aproveitamento Hidrelétrico de Simplício, AHE-Simplício). 


\section{MATERIALS AND METHODS}

The AHE-Simplício is designed to serve an estimated demand for $180 \mathrm{MW}$ of hydroeletric power in the southeastern region of Brazil. It is located in the lower-middle section of the Paraíba do Sul River, and is divided between the states of Minas Gerais (Além Paraíba and Chiador municipalities) and Rio de Janeiro (Três Rios and Sapucaia municipalities). Além Paraíba is located at $21^{\circ} 53^{\prime} 16^{\prime \prime}$ $\mathrm{S}, 42^{\circ} 42^{\prime} 16^{\prime \prime} \mathrm{W}, 140 \mathrm{~m}$ altitude; Chiador is located at $22^{\circ} 00^{\prime} 09^{\prime \prime} \mathrm{S}$, $43^{\circ} 03^{\prime} 28^{\prime \prime}$ W, $332 \mathrm{~m}$ altitude; Sapucaia is located at $21^{\circ} 59^{\prime} 42^{\prime \prime} \mathrm{S}$, $42^{\circ} 54^{\prime} 52^{\prime \prime} \mathrm{W}, 221 \mathrm{~m}$ altitude; and Três Rios is located at $22^{\circ} 07^{\prime} 00^{\prime \prime}$ $\mathrm{S}, 43^{\circ} 12^{\prime} 33^{\prime \prime} \mathrm{W}, 269 \mathrm{~m}$ altitude (Fig. 1). The vegetation of the study area consists of altered native "Atlantic Forest," pastures, and remnants of woody vegetation (Geroe, 1995). The mesothermal climate of the study area consists of hot and rainy summers, with a maximum temperature of $37.4^{\circ} \mathrm{C}$ and a minimum temperature of $14.2^{\circ} \mathrm{C}$, according to the Köppen (1948) climate classification.

From December 2008 to December 2009, captures of Culicidae were conducted from 18:00 to 10:00 the next morning every two months, compensating for daylight savings time. All captures occurred before the filling of the hydroelectric power plant reservoir. Mosquitoes were captured using two types of light traps, CDC automatic (Centers for Disease Control and Prevention) and Shannon (1939), with the help of an oral suction tube. CDC traps were installed in two different environments with, only light attraction. The first was fixed in a livestock shelter, while the second was fixed in secondary vegetation of the Atlantic Forest. At the sampling sites, the distance between the Shannon trap and the CDC trap located in the forest was $900 \mathrm{~m}$.

Four sampling sites were established: Collection sites A and B, characterized by secondary vegetation of the Atlantic Forest, floris- tic restoration similar to the original structure, recomposition with predominantly bamboo grove monoculture, intense anthropic action and richness in ornamental plants typical of the region; and collection sites $C$ and $D$, characterized by forest area with altered native vegetation and direct influence by the Paraiba do Sul River.

Captured specimens were placed in polyethylene cages, labeled according to origin, stored in coolers, and transported live to the laboratory. Thereafter, the mosquitoes were euthanized by exposure to chloroform.

Species determination of Culicidae was conducted by direct observation of morphological characteristics by stereomicroscope and based on the dichotomous keys developed by Lane and Cerqueira (1942), Lane (1953), Faran and Linthicum (1981), Consoli and Lourenço-De-Oliveira (1994) and Forattini (2002). The names and abbreviations for genera and subgenera follow those proposed by Reinert (2001). After species determination, all specimens were incorporated into the Entomological Collection of the Oswaldo Cruz Institute (Coleção Entomológica do Instituto Oswaldo Cruz). For classification of species in tribe Aedini, recommendations from the Journal of Medical Entomology (Editorial, 2005) were followed. These recommendations state that Ochlerotatus should be treated as a subgenus within the genus Aedes, as opposed to Reinert (2000), which proposes Ochlerotatus as a separate genus.

Since the majority of Culex specimens collected were adult females and identifying the few collected males proved to be difficult, individuals were identified at the generic level.

Comparisons between the number of mosquito species composing the sample collection found at the different collection sites were analyzed using the Kruskal-Wallis $(H)$ test. The Kruskal-Wallis $(H)$ test is based on the analysis of variance for the classification of small samples and allows for the evaluation of "K" independent

\section{1}

São José farm S $21^{\circ} 55^{\prime} 28.4^{\prime \prime}$ e W $42^{\circ} 49^{\prime} 08.9^{\prime \prime}$

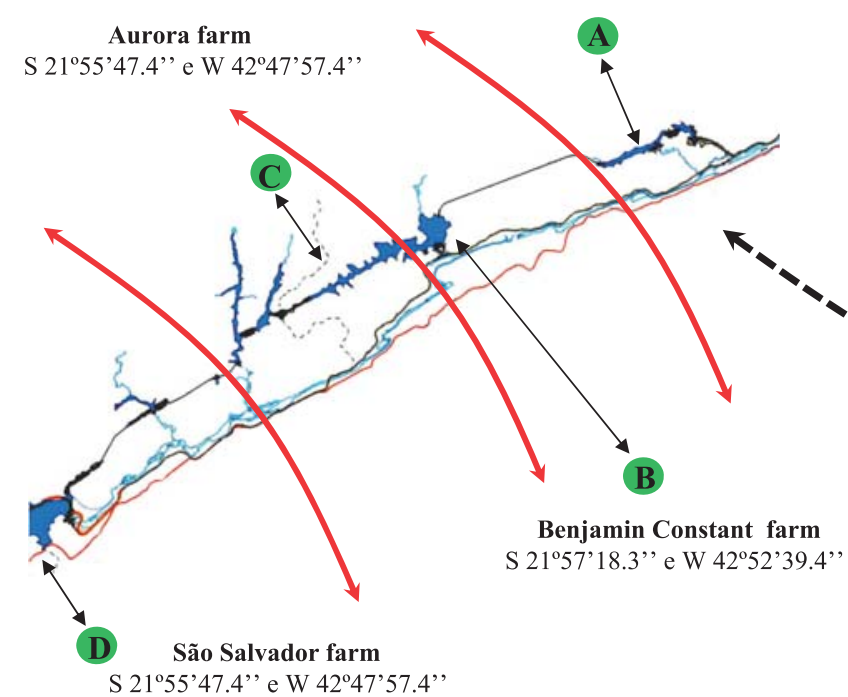

Collection sites : A, B, C, D

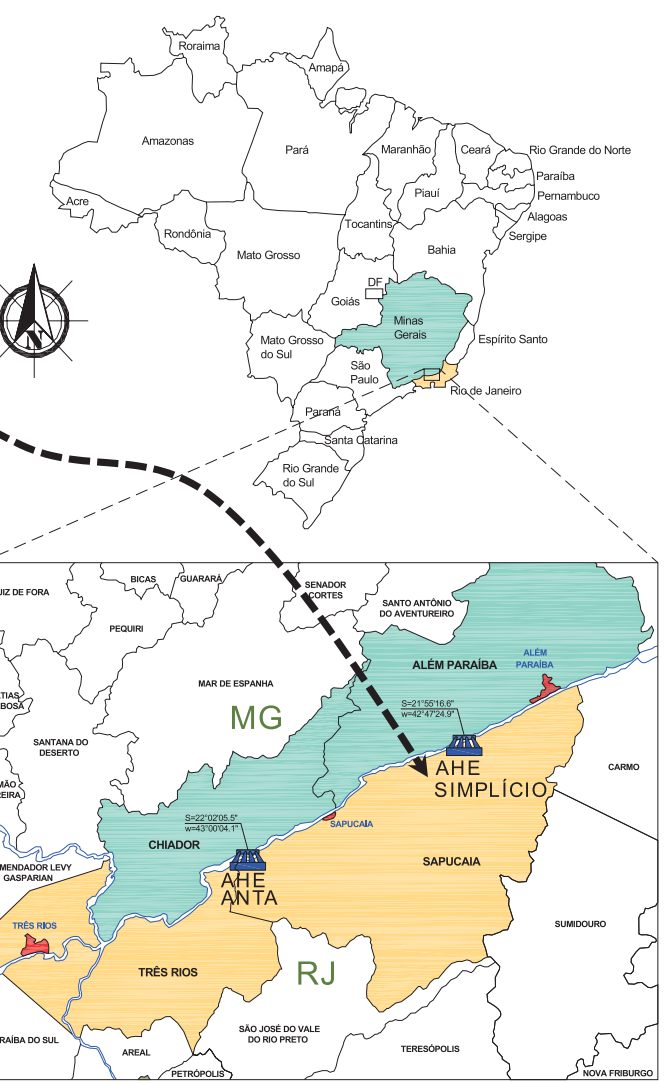

Fig. 1. Locations of mosquito capture sites in the area surrounding the Paraíba do Sul River, including the areas flooded by the reservoir of the Hydroelectric scheme of Simplício (HSS- Simplício). * Collection sites: A, B, C, D 
samples from different populations. For this study, a significance level of $5 \%(P<0.05)$ was considered statistically significant. This test analyzes the $H_{0}$ (null hypothesis) that the "K" samples are indistinguishable from the measures of central tendency (Serra-Freire, 2002).

The partial correlation test was used to assess the relationship between two variables, while controlling for the effect of a third variable. In this investigation, the correlation between each capture area $(\mathrm{X})$ with the quantity of species captured $(\mathrm{Y})$ was assessed, controlling for the type of trap (Z).

$H_{0}=$ type of trap does not influence the correlation between number of species of mosquitoes captured in the different study areas $(\alpha=5 \%)$.

\section{RESULTS}

We collected 1,474 mosquito specimens belonging to 35 species (Table 1). Eleven of the identified species repre- sented $1 \%$ or more of total specimens collected. Among these 11 species, some of the identified species have been identified as vectors of disease agents to humans and/or other animals, in particular: Anopheles aquasalis Curry, 1932, Aedes albopictus (Skuse, 1894), Coquillettidia venezuelensis (Theobald, 1912), Haemagogus leucocelaenus (Dyar and Shannon, 1924), Aedes scapularis (Rondani, 1848), and some species of the tribe Sabethini (Table 1).

The most frequently identified species at all four collection sites were Cq. fasciolata Lynch-Arribálzaga, 1891, (23.9\%), Ch. fajardi Lutz, 1904, (10.5\%), An. evansae (Brèthes, 1926) (5.6\%) and Ae. serratus (Theobald, 1901) $(4.8 \%)$ (Table 1$)$. Of specimens collected, $40.2 \%$ corresponded to genus Culex, which may include more than one species. Among the species with lower population numbers

Table 1. Absolute values and percentages of mosquito species found around the reservoir of the Hydroelectric scheme of Simplício (HSS-Simplício), the occurrence of species per capture site and the occurrence of species overall for all capture sites during the period December 2008 to December 2009.

\begin{tabular}{|c|c|c|c|c|c|c|c|c|c|c|}
\hline \multirow{2}{*}{ Species } & \multicolumn{2}{|c|}{ Site A } & \multicolumn{2}{|c|}{ Site B } & \multicolumn{2}{|c|}{ Site C } & \multicolumn{2}{|c|}{ Site D } & \multicolumn{2}{|c|}{ Total } \\
\hline & $\mathrm{N}$ & $\%$ & $\mathrm{~N}$ & $\%$ & $\mathrm{~N}$ & $\%$ & $\mathrm{~N}$ & $\%$ & $\mathrm{~N}$ & $\%$ \\
\hline An. (Nys.) albitarsis Lynch-Arribálzaga, 1878 & 0 & $0.0 \%$ & 1 & $0.3 \%$ & 0 & $0.0 \%$ & 0 & $0.0 \%$ & 1 & $0.1 \%$ \\
\hline An. (Nys.) aquasalis Curry, 1932 & 0 & $0.0 \%$ & 8 & $2.4 \%$ & 0 & $0.0 \%$ & 1 & $0.6 \%$ & 9 & $0.6 \%$ \\
\hline An. (Nys.) argyritarsis Robineau-Desvoidy, 1827 & 0 & $0.0 \%$ & 4 & $1.2 \%$ & 1 & $0.1 \%$ & 0 & $0.0 \%$ & 5 & $0.3 \%$ \\
\hline An. (Nys.) evansae (Brèthes, 1926) & 4 & $1.6 \%$ & 67 & $19.8 \%$ & 3 & $0.4 \%$ & 8 & $4.9 \%$ & 82 & $5.6 \%$ \\
\hline An. (Ano.) fluminensis Root, 1927 & 0 & $0.0 \%$ & 4 & $1.2 \%$ & 8 & $1.1 \%$ & 0 & $0.0 \%$ & 12 & $0.8 \%$ \\
\hline An. (Nys.) galvaoi Causey, Deane \& Deane, 1943 & 0 & $0.0 \%$ & 0 & $0.0 \%$ & 2 & $0.3 \%$ & 0 & $0.0 \%$ & 2 & $0.1 \%$ \\
\hline An. (Nys.) rangeli Gabaldon, Cova Garcia \& Lopez, 1940 & 1 & $0.4 \%$ & 17 & $5.0 \%$ & 4 & $0.6 \%$ & 0 & $0.0 \%$ & 22 & $1.5 \%$ \\
\hline An. (Nys.) lutzii Cruz, 1901 & 1 & $0.4 \%$ & 0 & $0.0 \%$ & 0 & $0.0 \%$ & 0 & $0.0 \%$ & 1 & $0.1 \%$ \\
\hline An. (Ano.) mediopunctatus (Theobald, 1903) & 0 & $0.0 \%$ & 0 & $0.0 \%$ & 1 & $0.1 \%$ & 0 & $0.0 \%$ & 1 & $0.1 \%$ \\
\hline An. (Nys.) strodei Root, 1926 & 0 & $0.0 \%$ & 10 & $3.0 \%$ & 6 & $0.8 \%$ & 0 & $0.0 \%$ & 16 & $1.1 \%$ \\
\hline An. (Nys.) triannulatus (Neiva \& Pinto, 1922) & 0 & $0.0 \%$ & 3 & $0.9 \%$ & 0 & $0.0 \%$ & 0 & $0.0 \%$ & 3 & $0.2 \%$ \\
\hline Ch. fajardi Lutz, 1904 & 6 & $2.4 \%$ & 114 & $33.7 \%$ & 25 & $3.5 \%$ & 9 & $5.6 \%$ & 154 & $10.5 \%$ \\
\hline Ae. (Stg.) albopictus (Skuse, 1894) & 26 & $10.4 \%$ & 0 & $0.0 \%$ & 2 & $0.3 \%$ & 2 & $1.2 \%$ & 30 & $2.0 \%$ \\
\hline Ae. (Pro.) argyrothorax Bonne-Wepster \& Bonne, 1919 & 2 & $0.8 \%$ & 2 & $0.6 \%$ & 0 & $0.0 \%$ & 0 & $0.0 \%$ & 4 & $0.3 \%$ \\
\hline Ae. (Och.) fluviatilis (Lutz, 1904) & 1 & $0.4 \%$ & 10 & $3.0 \%$ & 2 & $0.3 \%$ & 1 & $0.6 \%$ & 14 & $0.9 \%$ \\
\hline Ae. (Och.) scapularis (Rondani, 1848) & 4 & $1.6 \%$ & 8 & $2.4 \%$ & 7 & $1.0 \%$ & 25 & $15.4 \%$ & 44 & $3.0 \%$ \\
\hline Ae. (Och.) serratus (Theobald, 1901) & 1 & $0.4 \%$ & 8 & $2.4 \%$ & 30 & $4.2 \%$ & 32 & $19.8 \%$ & 71 & $4.8 \%$ \\
\hline Cq. (Rhy.) chrysonotum (Peryassú, 1922) & 39 & $15.7 \%$ & 0 & $0.0 \%$ & 2 & $0.3 \%$ & 1 & $0.6 \%$ & 42 & $2.8 \%$ \\
\hline Cq. (Rhy.) fasciolata Lynch-Arribálzaga, 1891 & 27 & $10.8 \%$ & 20 & $5.9 \%$ & 284 & $39.4 \%$ & 21 & $13.0 \%$ & 352 & $23.9 \%$ \\
\hline Cq. (Rhy.) juxtamansonia (Chagas, 1907) & 17 & $6.8 \%$ & 0 & $0.0 \%$ & 36 & $5.0 \%$ & 0 & $0.0 \%$ & 53 & $3.6 \%$ \\
\hline Cq. (Rhy.) venezuelensis (Theobald, 1912) & 1 & $0.4 \%$ & 5 & $1.5 \%$ & 2 & $0.3 \%$ & 2 & $1.2 \%$ & 10 & $0.7 \%$ \\
\hline Culex spp. Linnaeus, 1758 & 107 & $43.0 \%$ & 157 & $46.4 \%$ & 309 & $42.9 \%$ & 20 & $12.3 \%$ & 593 & $40.2 \%$ \\
\hline Hg. (Con.) leucocelaenus (Dyar \& Shannon, 1924) & 1 & $0.4 \%$ & 1 & $0.3 \%$ & 0 & $0.0 \%$ & 0 & $0.0 \%$ & 2 & $0.1 \%$ \\
\hline Li. durhamii Theobald, 1901 & 1 & $0.4 \%$ & 1 & $0.3 \%$ & 0 & $0.0 \%$ & 2 & $1.2 \%$ & 4 & $0.3 \%$ \\
\hline Ma. (Man.) titillans (Walker, 1848) & 2 & $0.8 \%$ & 4 & $1.2 \%$ & 3 & $0.4 \%$ & 1 & $0.6 \%$ & 10 & $0.7 \%$ \\
\hline Ps. (Jan.) albipes (Theobald, 1907) & 0 & $0.0 \%$ & 0 & $0.0 \%$ & 1 & $0.1 \%$ & 1 & $0.6 \%$ & 2 & $0.1 \%$ \\
\hline Ps. (Jan.) ferox (Von Humboldt, 1819) & 2 & $0.8 \%$ & 5 & $1.5 \%$ & 5 & $0.7 \%$ & 39 & $24.1 \%$ & 51 & $3.5 \%$ \\
\hline Sa. (Sab.) albiprivus Theobald, 1903 & 3 & $1.2 \%$ & 0 & $0.0 \%$ & 0 & $0.0 \%$ & 0 & $0.0 \%$ & 3 & $0.2 \%$ \\
\hline Sa. (Sbo.) chloropterus (Von Humboldt, 1819) & 2 & $0.8 \%$ & 0 & $0.0 \%$ & 0 & $0.0 \%$ & 0 & $0.0 \%$ & 2 & $0.1 \%$ \\
\hline Sa. (Pey.) identicus Dyar \& Knab, 1907 & 0 & $0.0 \%$ & 0 & $0.0 \%$ & 8 & $1.1 \%$ & 4 & $2.5 \%$ & 12 & $0.8 \%$ \\
\hline Sa. (Pey.) soperi Lane \& Cerqueira, 1942 & 1 & $0.4 \%$ & 0 & $0.0 \%$ & 0 & $0.0 \%$ & 0 & $0.0 \%$ & 1 & $0.1 \%$ \\
\hline Sa. (Pey.) whitmani Lane \& Cerqueira, 1942 & 0 & $0.0 \%$ & 0 & $0.0 \%$ & 0 & $0.0 \%$ & 1 & $0.6 \%$ & 1 & $0.1 \%$ \\
\hline Tr. pallidiventer (Lutz, 1905) & 1 & $0.4 \%$ & 0 & $0.0 \%$ & 1 & $0.1 \%$ & 0 & $0.0 \%$ & 2 & $0.1 \%$ \\
\hline Ur. (Ura.) calosomata Dyar \& Knab, 1907 & 4 & $1.6 \%$ & 1 & $0.3 \%$ & 2 & $0.3 \%$ & 0 & $0.0 \%$ & 7 & $0.5 \%$ \\
\hline Ur. (Ura.) geometrica Theobald, 1901 & 0 & $0.0 \%$ & 1 & $0.3 \%$ & 0 & $0.0 \%$ & 1 & $0.6 \%$ & 2 & $0.1 \%$ \\
\hline Wy. aporonoma Dyar and Knab, 1906 & 1 & $0.4 \%$ & 1 & $0.3 \%$ & 2 & $0.3 \%$ & 0 & $0.0 \%$ & 4 & $0.3 \%$ \\
\hline Total & 249 & $100.0 \%$ & 338 & $100.0 \%$ & 721 & $100.0 \%$ & 162 & $100.0 \%$ & 1474 & $100.0 \%$ \\
\hline
\end{tabular}

${ }^{\star}$ Collection sites $\mathrm{A}, \mathrm{B}, \mathrm{C}$ and $\mathrm{D} ; \mathrm{N}=$ Absolute values of mosquito; \% percentages of mosquito. 
collected by CDC trap, the occurrence of $\mathrm{Hg}$. leucocelaenus is noteworthy; this rare species is considered diurnal, and its occurrence may be explained by the rhythm of collection times, which included some daylight hours.

Low numbers of some species of Sabethes were collected by the CDC trap located in the livestock shelter outside of the forest. This behavior suggests that the feeding habits of these species are not restricted to forested areas, but could also occur in populated areas as well.

Efficacy between sampling methods conducted in capture sites $A$ and $C$ was not found to be significantly different in the Kruskal-Wallis test, regardless of species collected. Thus, collection methods used in the capture sites did not differ significantly by number of species (Table 2).

In the comparison of samples collected at site B, the efficacy of collection was found to be significantly different between the collection methods, regardless of species captured. A greater number of species and higher population density of specimens captured were observed for CDC light traps located in the livestock shelters (Table 2).

Capture sites $B$ and $C$ were the richest in species from genus Anopheles, with 11 different species captured from this genus. Of these 11 species, An. evansae represented the highest population density. Regarding the location of installation of the CDC and Shannon traps in the four capture sites studied, the CDC trap located in the livestock shelter was found to have better sampling efficacy as it achieved higher species richness.

Based on the result of the Dunn test, CDC and Shannon traps differed significantly by midpoint of collection efficacy.

Analyzing the three sampling sites, sites $A$ and $C$ presented higher tribe Sabethini species richness and density, as well as the largest population of Ae. albopictus. Among the samples collected using CDC light traps, the trap installed in the livestock shelter was found to have a greater population density of Ae. albopictus in comparison to Shannon and CDC traps located in forest areas.

For specimens collected at site $\mathrm{C}$, the comparison between the efficacies of the methods was found to be significantly different, irrespective of species (Table 2).

Performing the Dunn test for difference between the midpoints of the efficacy of the methods of capture, CDC X CDC livestock shelter and CDC livestock shelter $X$ Shannon were found to differ significantly, while for CDC X Shannon, the difference between midpoints was not significant.

Table 2. Comparison by Kruskal-Wallis test of the efficacy of mosquito captures conducted around the reservoir of the Hydroelectric scheme of Simplicio (HSS-Simplicio) at different collection sites, irrespective of species captured, during the period December 2008 to December 2009.

\begin{tabular}{ccccl}
\hline Sites & $\mathrm{H}$ & $\mathrm{Gl}$ & $\mathrm{p}$ & $\chi^{2}$ \\
\hline $\mathrm{A}$ & 4.3711 & 2 & 0.1124 & 5.991 - Not significant \\
$\mathrm{B}$ & 9.3523 & 2 & 0.0093 & 5.991 - Significant \\
$\mathrm{C}$ & 20.8821 & 2 & 0.00001 & 5.991 - Significant \\
$\mathrm{D}$ & 2.1414 & 2 & 0.3428 & 5.991 - Not significant \\
\hline All Sites & $\mathrm{H}$ & $\mathrm{Gl}$ & $\mathrm{p}$ & $\chi^{2}$ \\
$\mathrm{~A}+\mathrm{B}+\mathrm{C}+\mathrm{D}$ & 7.2492 & 3 & 0.0644 & $7.815-$ Not significant \\
\hline
\end{tabular}

${ }^{*}$ Collection sites: A, B, C and D; H: Coefficient Kruskal-Wallis; Gl:

Degree of freedom; $p$ : probabilit.
Results for site D also did not show significant difference (Table 2).

When the two methods of sampling between the four of capture sites were compared, regardless of the species of captured mosquitoes and the type of trap used, no significant difference was found. Capture site $C$ had a higher population density when compared to the other areas studied, containing $44.4 \%$ of all mosquitoes captured.

Poor correlation $\left(r_{\mathrm{x}, \mathrm{y}}=-0.0173\right)$ was observed between mosquito species richness and capture site, when the effects of collection method were excluded.

Similarly, an acceptable correlation $\left(r_{\mathrm{x}, \mathrm{y}, \mathrm{z}}=-0.3715\right)$ was observed between mosquito species richness and capture sites, without the influence of the type of trap used for sampling.

\section{DISCUSSION}

Hydroelectric projects produce considerable impacts on the environment and surrounding areas, both during and beyond the lifetime of the plant. Faunal studies conducted in areas with this type of configuration can support identification, monitoring and control, especially for mosquito populations confronting anthropogenic environmental changes. These implications can include the degradation or preservation of a given area and/or the epidemiological implications of these changes, particularly in the Atlantic Forest biome (Forattini and Massad, 1998).

Azevedo (1997) and Guimarães et al. (2000) suggested respectively the possibility of malaria transmission in areas of Atlantic Forest in the states of Sao Paulo and Rio de Janeiro, respectively, as a function of new movements in human ecology. Thus, the emergence of epidemics could be directly related to problems of human ecology caused by large-scale environmental projects, such as the flooding of areas to form hydroelectric plant reservoirs.

Although investigations on the ecological characteristics of culicid fauna have been conducted in various areas of the Brazilian territory, these studies have been conducted mainly due to the presence of certain transmitters of infectious agents within urban environments (Alencar et al., 2011).

The attraction of insects to light depends on the sensitivity of receptors to different wavelengths which are distinctly different from those of mammals and humans. According to the observations of Brioscoe and Chittka (2001), the light sensitivity of Culicidae is between $350 \mathrm{~nm}$ and $600 \mathrm{~nm}$, while the light sensitivity of humans is between $420 \mathrm{~nm}$ and $680 \mathrm{~nm}$. Following studies of insect phototropism and the advent of new light sources, light traps have become widely used (Silveira Neto et al., 1976). These light traps have been developed to assist in the capture of insects, in particular the Culicidae, and have been effective in wildlife surveys and population dynamics studies on insects (Forattini, 2002).

Using CDC light traps and Shannon as sampling methods, the pattern of mosquito species richness for different capture sites was clearly demonstrated to be influenced strongly by the predominance of Cq. fasciolata in comparison to other species. This pattern seems to have been directly affected by the intense anthropogenic activity at the capture site, as noted in samples taken by the Shannon 
trap. Differences in yield between the techniques used to study the composition of mosquito fauna collected simultaneously by the CDC and Shannon were observed.

In the present study, the number of specimens collected using Shannon light traps was higher in all capture sites and, among the anophelines, An. evansae exhibited the highest population density. According to Lourenço-deOliveira et al. (1989), An. evansae is essentially zoophilic and exophilic, and its frequency is not related to the epidemiology of malaria.

Dutra et al. (1996) also demonstrated a higher population density of genus Anopheles in samples collected using Shannon traps.

Despite typically being characterized as diurnal and considered a bioindicator of preserved environment, we discovered the presence of some sabethine species in both types of traps used. This behavior may have been influenced by the light emitted from the traps.

Since collection was conducted after 18:00 using CDC traps, behavior uncharacteristic of the bionomics of $\mathrm{Hg}$. leucocelaenus was observed during the sampling period. This species is a potential vector of the yellow fever virus and is characterized as essentially diurnal and acrodendrofilic (Forattini, 2002).

In conclusion, despite the strong environmental impact on the study area due to the construction of the hydroelectric reservoir, the mosquito fauna demonstrated a relatively high richness, including the presence of some species of great epidemiological importance. Moreover, the abundance of mosquitoes sampled for the various collection sites was not influenced by type of trap used.

\section{ACKNOWLEDGMENTS}

This work was accomplished with the help of Furnas Centrais Elétricas S.A. (contract. P-1031-00-PJ-/08)

\section{REFERENCES}

Alencar J, Ferreira ZM, Catarina ML, Serra-Freire NM, Mello RP, Silva JS, et al. (2011) Biodiversity and Times of Activity of Mosquitoes (Diptera: Culicidae) in the Biome of the Atlantic Forest in the State of Rio de Janeiro, Brazil. J Med Entomol 48: 223231

Azevedo AL (1997) Aspectos da Epidemiologia da Malária e da Biologia de Anopheles (Kertezia) cruzii Dyar \& Knab em Vales Montanhosos do Sistema de Mata Atlântica. MSc Thesis, Mem Inst Oswaldo Cruz, p 94

Brioscoe AD, Chittka L (2001) The evolution of color vision in insects. Ann Rev Ent 46: 471-510

Consoli RAGB, Lourenço-de-Oliveira R (1994) Principais mosquitos de importância sanitária no Brasil. Editora Fiocruz, Rio de Janeiro, p 228

Dutra AP, Natal D, Tubaki RM, Barata JMS, Menezes RMT, Urbinatti PR, et al. (1996) Mosquitos (Diptera: Culicidae) da
Reserva Estadual de Pedro de Toledo (Juquitiba, SP, Brasil). Rev bras Ent 40: 375-378

Editorial (2005) Journal policy on names of Aedini mosquito genera and subgenera. J Med Entomol 42 (4): 511

Faran ME, Linthicum KJ (1981) A handbook of the Amazonian species of Anopheles (Nyssorhynchus) (Diptera: Culicidae). Mosq Syst 13: 1-81

Forattini OP (1991) Qualidade de vida e meio urbano. A cidade de São Paulo, Brasil. Rev Saúde pública, São Paulo 25: 75-86

Forattini OP (2002) Culicidologia Médica. EDSP, São Paulo, p 860

Forattini OP, Massad E (1998) Culicidae vectors and anthropic changes in a southern Brazil natural ecosystem. Ecosyst Health 4: 9-19

Geroe (Grupo Executivo para Recuperação e Obras de Emergência) (1995) Mapa de cobertura vegetal e uso do solo do Estado do Rio de Janeiro e da bacia hidrográfica do Rio Paraíba do Sul

Guimarães AE, Mello RP, Lopes CM, Alencar J, Gentile C (1997) Prevalência de anofelinos (Diptera: Culicidae) no crepúsculo vespertino em áreas da Usina Hidrelétrica de Itaipu, no município de Guaíra, estado do Paraná, Brasil. Mem Inst Oswaldo Cruz 92: 745-754

Guimarães AE, Mello RP, Lopes CM, Gentile C (2000) Ecology of mosquitoes (Diptera: Culicidae) in areas of Serra do Mar State, State os São Paulo, Brazil. I-Monthly frequency and climatic factors. Mem Inst Oswaldo Cruz 95:1-16

Köppen W (1948) Climatologia, com un studio de los climas de la tierra. Fondo de Cultura Economica, Mexico, p 478

Lane J (1953) Neotropical Culicidae. vol. 2. EDUSP, São Paulo, p 1112

Lane J, Cerqueira NL (1942) Os sabetineos da América (Diptera, Culicidae). Arch Zool S Paulo 3: 473-849

Lourenço-de-Oliveira R, Guimarães AE, Arlé M, Silva TF, Castro MG, Motta MA, et al. (1989) Anopheline species, some of their habits and relation to malaria in endemic areas of Rondônia Satate, Amazon Region of Brazil. Mem Inst Oswaldo Cruz 84: $501-514$

Reinert JF (2000) New classification for the composite genus Aedes (Diptera: Culicidae: Aedini), elevation of subgenus Ochlerotatus to generic rank, reclassification of the other subgenera and notes on certain subgenera and species. J Am Mosq Contrl Assoc 16: 175-188.

Reinert JF (2001) Revised list of abbreviations for genera and subgenera of Culicidae (Diptera) and notes on generic and subgeneric changes. J Am Mosq Control Assoc 17: 51-55

Rueda LM (2008) Global diversity of mosquitoes (Insecta: Diptera: Culicidae) in freshwater. Hydrobiologia 595: 477-487

Serra-Freire NM (2002) Planejamento e Análise de Pesquisas Parasitológicas. Niterói: Editora UFF, p 195

Shannon R (1939) Methods for collecting and feeding mosquitos in jungle yellow fever studies. Amer Journ Trop Med 19: 131-140

Silveira Neto S, Nakano O, Barbin D, Nova NAV (1976) Manual de Ecologia dos Insetos. São Paulo: Editora Agronômica Ceres, $p$ 419

(Received August 17, 2011 / Accepted December 4, 2011) 